\title{
ECONOMY
}

\section{REFORMATTING UKRAINIAN BUDGET SYSTEM WITHIN THE CONDITIONS OF POWER DECENTRALIZATION}

\author{
PhD in Economics, Associate Professor Inna Hnydiuk \\ Ukraine, Vinnytsia, Vinnytsia Institute of Trade and Economics of Kyiv National University of Trade \\ and Economics
}

DOI: https://doi.org/10.31435/rsglobal_ws/31012020/6897

\section{ARTICLE INFO}

Received: 08 November 2019

Accepted: 12 January 2020

Published: 31 January 2020

\section{KEYWORDS}

budget system, local budget, territorial community, associating principle, subsidiarity principle, inter-budget balance. \begin{abstract}
The article provides a renovated structure of the state budget system, including location and role of the budgets of joint territorial communities. Besides, current research analyzes the impact of Tax and Budget transformations on the financial framework development of the bodies of local self-authorities, implemented in the beginning of 2015. Special attention has been paid by the authors of the article to the budget balance. Major powers and functions of the bodies of local authority have been studied, according to the European Charter of Local Authority.
\end{abstract}

Citation: Inna Hnydiuk. (2020) Reformatting Ukrainian Budget System within the Conditions of Power Decentralization. World Science. 1(53), Vol.2. doi: 10.31435/rsglobal_ws/31012020/6897

Copyright: (C) 2020 Inna Hnydiuk. This is an open-access article distributed under the terms of the Creative Commons Attribution License (CC BY). The use, distribution or reproduction in other forums is permitted, provided the original author(s) or licensor are credited and that the original publication in this journal is cited, in accordance with accepted academic practice. No use, distribution or reproduction is permitted which does not comply with these terms.

Introduction. Nowadays there still exist numerous unsolved problems in the context of formatting the renovated budget structure, considering the definitions of budget decentralization and identifying location, role and importance of the territorial community within this structure.

The objective of this paper is to justify the directions of Ukrainian budget system reforming within the conditions of power decentralization.

Investigation methods: the research has been conducted through such methods as observation method (in the process of budget system structure identifying under the impact of the latest changes within Budget and Tax Code and intensified directing towards administrative-territorial reforming in Ukraine); method of system-structural and functional analysis (in the process of examining the state and the trends of budget system functioning, and developing its new model).

Basic results of the research. The article provides a renovated structure of the state budget system, including location and role of the budgets of joint territorial communities. Besides, current research analyzes the impact of Tax and Budget transformations on the financial framework development of the bodies of local self-authorities, implemented in the beginning of 2015. Special attention has been paid by the authors of the article to the budget balance. Major powers and functions of the bodies of local authority have been studied, according to the European Charter of Local Authority.

Target setting. Throughout the years of Ukrainian independence, backgrounds of the state budget system have been created, and the number of legislative orders about budget process limitation have been adopted. Although, nowadays there still exist many unsolved problems of developing a renovated budget system structure comprising budget decentralization definitions, as well as identification of location, role and importance of the territorial community within this structure. 
Actual scientific researches and issues analysis. Recent researches of such authors as O.D. Vasylyk, K.V. Pavlyuk, Y.V. Pasichnyk, V.M. Fedosov, I.Y. Chugunov and S.I. Yuriy have been dedicated to the problems of creating and developing budget system of a country. Although, modern scientific-economic literature does not fully covers the problem of reformatting Ukrainian budget system in the conditions of administrative-territorial reforming. Conceptual principles of the budget decentralization, based on the acceptance of local and national interests' differences, have been analyzed in the works of R. Bird, V. Bratik, D. Bouks, D. Bukenen, R. Massgrve and others.

Regardless of the remarkable scientific achievements of the researchers within the investigation of the underlined problematics, issues of identifying the directions of Ukrainian budget system modernization within the conditions of decentralization remain unclear. Transit of remarkable powers from the upper level to the lower one, accumulation of financial resources of the local levels, introduction of a new administrative-territorial unit, such as joint territorial community, and setting its location within the structure of Ukrainian budget system, determined the choice of the research topic.

Article objective. Taking into consideration the necessity for solving the problems accumulate in this field of Ukrainian economy, it is worth updating the investigations of the efficient Ukrainian budget system. Therefore, the objective of this paper is to justify the directions of Ukrainian budget system reforming within the conditions of power decentralization.

The statement of basic materials. Alongside with the introduction of new Budget Code of Ukraine in 2001, the construction of its own model of budget relationship started. Budget system of Ukraine is composed of local budgets and State budget of Ukraine (Fig.1.). On January 1, 2018, there were 9060 units of local budget (excluding local budgets of AR Crimea, Sevastopol city and area of ATO), 1288 of which were involved in the direct correspondence with the state budget.

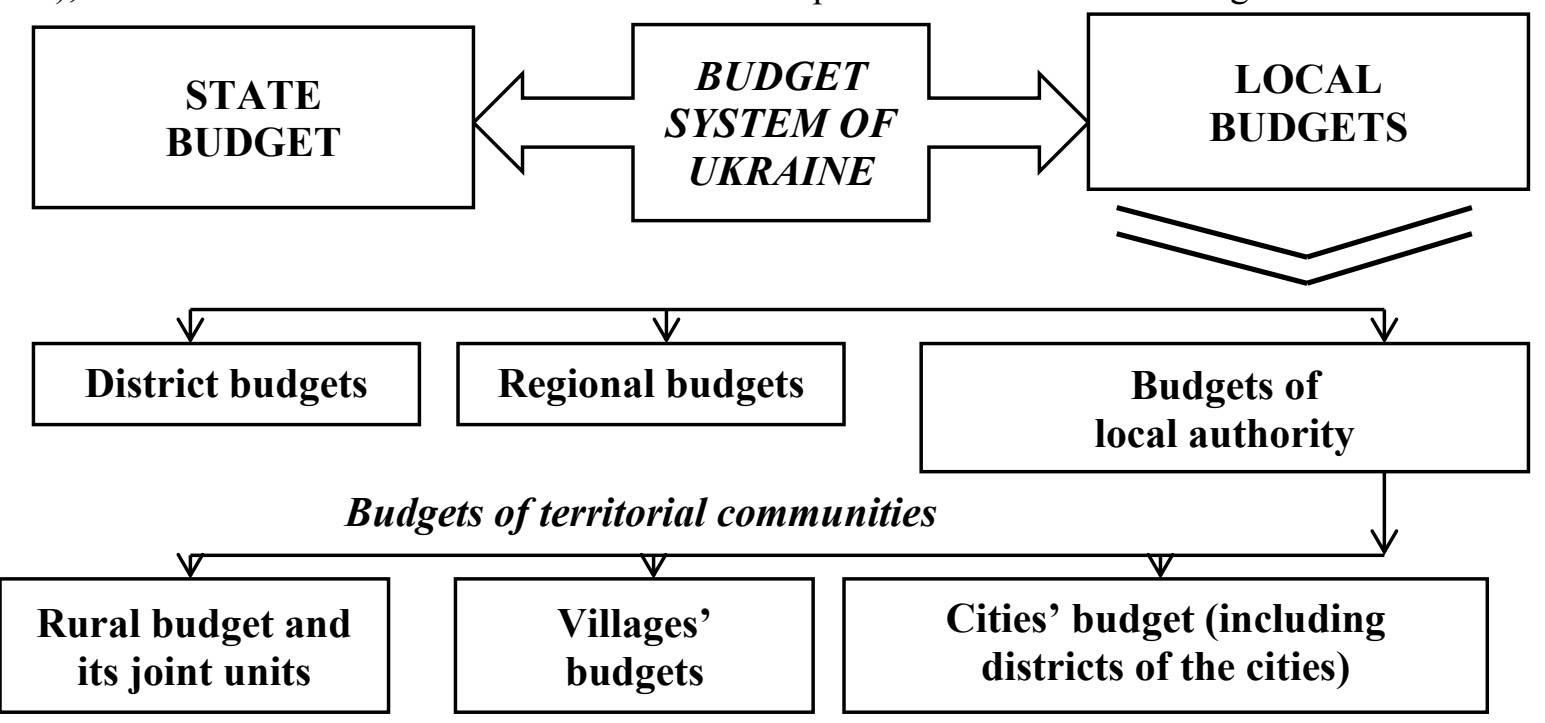

Fig. 1. Structure of the Budget System of Ukraine

Source: has been derived by the authors from [3]

Each of the budgets does not directly subordinates to the upper level budget and operates as an individual body. Budgets' individuality can be guaranteed only by possessing its own financial resources and ensuring the right of choosing directions of their usage by the correlative bodies of state power.

It is worth mentioning, that the state is not responsible for budget duties of the local authority bodies by means of state budget capital, and local authority bodies, in turn, are not responsible for the budget duties of each other (as well as for budget duties of the state) by means of the corresponding local budgets.

At the same time, the basis of the budget system development is the principle of unity. It indicates the operation of a single common account for income and expenditure of every component of budget system. Associating of the budget system is proved by the common legal framework, common budget classification, common regulation of budget relationship, common monetary system, unity of the order of budget implementation, as well as accountings and reports conducting.

Amendments to the Tax and Budget Codes, adopted in December 2014 and the Law of Ukraine "About the State Budget of Ukraine for 2015", composed upon new financial basis of the local budgets, 
should be considered as the first steps of the Parliament and the Government towards the implementation of decentralization reforming [5].

Adopted legislative transformations were directed towards:

1. Enhancing financial and budget individuality of the local communities' budgets:

- individual formatting of local budgets, basing on assigned steady profitable resources and expenditure powers, as well as basic options, defined in the draft of the state budget, submitted by the Government to the Parliament before September 15, preceding the planned one (ch. $75 \mathrm{BCU}$ );

- irrespective of the date of state budget adoption, formatting and approval of local budgets should be carried out before December 25 of each year, preceding the planned one 3 (ch. $77 \mathrm{BCU}$ );

- the procedure of providing local guarantees and fulfilling local borrowings from the international financial organizations through implementation of the "Silent agreement" principle and consenting such operations with the Ministry of Finance has been simplified (ch. 74 BCU) [1].

2. Extending current profitable framework of the local budgets through:

- transferring payment for administrative services from the state budget (with the exception of $50 \%$ of administrative fee for state registration of material rights for property and its burdens, as well as state registration of legal entities and individuals - entrepreneurs), and state custom;

- increase of interest rate of ecological tax calculation from $35 \%$ to $80 \%$;

- relief of steady resources of the local budgets - tax for individual's incomes according to new regulations (budgets of cities of regional and district importance $-60 \%$, regional budgets $-15 \%$, budget of Kyiv $-40 \%$ ) and tax for private enterprise incomes (regional budgets - 10\%);

- launching of retail sale of excisable goods since 2015 (beer, alcohol beverages, tobacco, oil products) with 5\% rate of the retailed goods instead of fee for viniculture, gardening and hop growing, transferred to the local budgets;

- extending taxation imposing for property through enrolling commercial (non-residential) property to the list of taxation since 2015 .

3. Decentralization of expenditure powers within social-cultural field and precise division of the competences, composed in accordance with the subsidiary principles. Separate arrangements and institutions of educational and cultural sphere are transferred from the state level to regional and city levels; support of the separate boards, sport-physical communities, and their frameworks and others.

4. Launching new types of transfers (general subsidy, educational subvention, subvention for labor staff training, medical subvention; subvention for providing separate state programs and programed complex arrangements to the medical institutions, reverse subsidy) [4, c. 45-49 ].

General subsidy is compensational by nature and justifies reaching balance of tax fiscal capacity of the local budgets according to the assigned profits (tax for individuals' incomes, tax for profits).

The mechanism of dividing and application of new subventions within the area of administrative-territorial units has been identified.

5. Enhancing the responsibility of specialized ministries for the implementation of the state educational and medical policy by means of determining them as the major capital delivers of the corresponding subventions.

6. Providing the right for individual choice of the institution (Treasury bodies or banking institutions) for monetary services of local budget development and particular earnings of the budget institutions.

7. Simplifying the procedure, providing local guarantees and borrowings, withdrawn from the international financial institutions.

8. Changes of the distinguishing process between earnings enrolled from ecological taxation (except the tax appointed for production radioactive wastes) with anticipation of enrolling $20 \%$ of the earnings to the state budget and $80 \%$ - to the local budgets, including $55 \%$ - to the regional budgets, $25 \%$ - rural, village and city budgets, and $80 \%$ - to the budget of Kyiv.

9. Application of the new system of budget balancing.

System of budget balance, operating in Ukraine till 2015, based on the expenditures, did not motivate neither the so-called "poor" or dotational territorial communities to improve and optimize their budget nettings, nor prosperous budget bodies of local authority - to extend their income framework in future. As far as a dotation is decreased in the first case, a withdrawing increases in the second case. In December 2014, conceptual changes of the inter-budget balance were adopted. The system of budget balancing had been substituted by the system of the horizontal balancing of tax fiscal capacity. The main idea of the new system proves that balancing is reached through the assigned common state taxations (tax for 
individual's incomes and tax for profit) depending upon the level of earnings for a single citizen. All other payments remained in the disposal of the bodies of local authority and were not subjected for balancing.

Horizontal balancing expects division of the local budgets into three groups (Fig. 2).

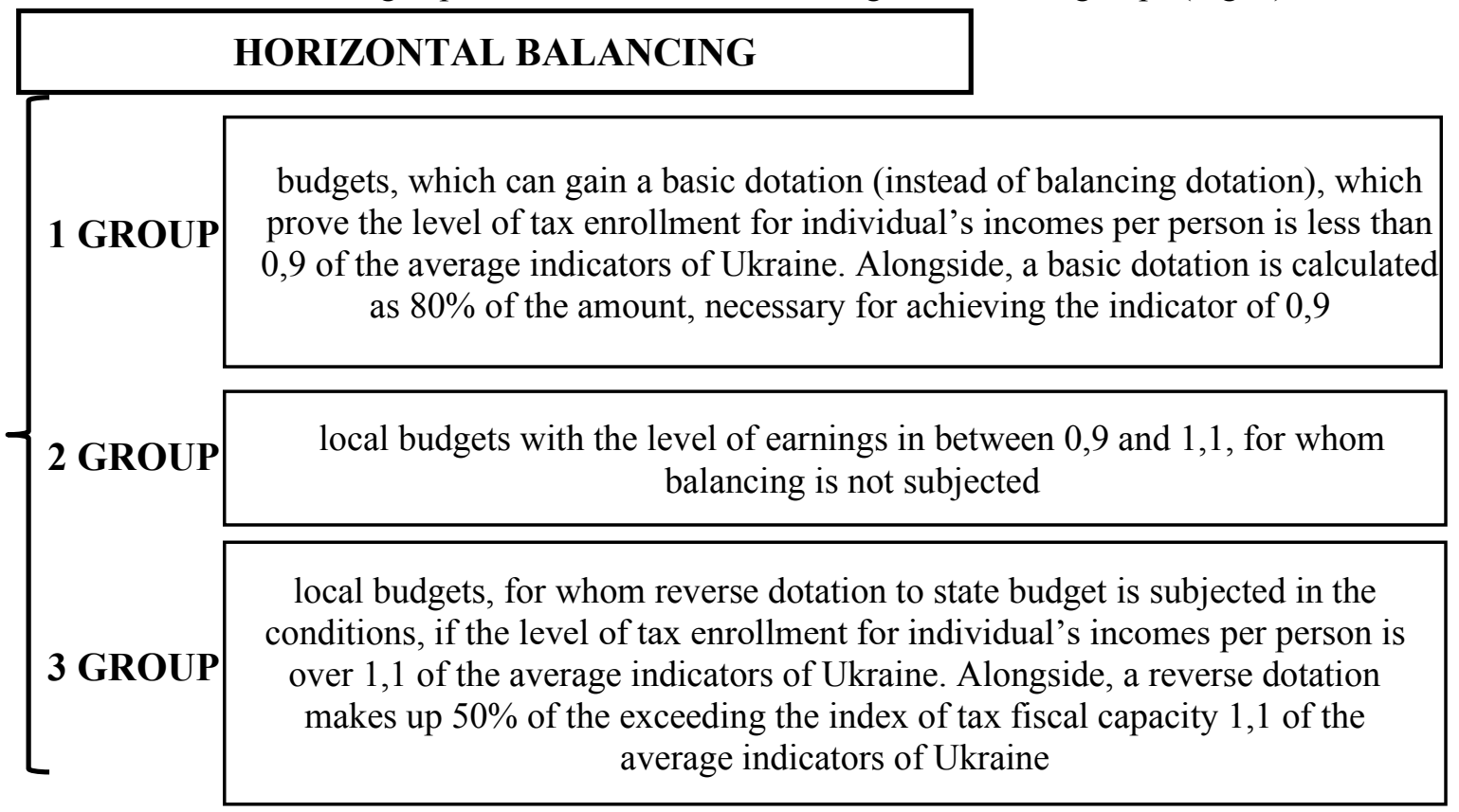

Fig.2. Division of Local Budgets at Horizontal Balancing

Source: has been derived by the authors from [4]

Such approach motivates local authority bodies to involve additional earnings and to extend taxation framework, and, mainly, it encourages supporting local budgets with sufficient earnings.

As for the income section, according to the current legislature, budget incomes cover two major components: incomes of the general fund and incomes of the special funds. General fund focuses state assigned finance, which is subjected for further distribution. Special fund accumulates finance of budget institutions, including special state funds, which are not expected to be distributed and are used with target nomination.

According to the standards of Chapter 64 of the Budget Code of Ukraine, incomes of the general fund of the budgets of cities of regional importance, regional budgets and joint communities' budgets, created agreeing with the Law and Perspective Plan of territorial communities building, include:

- $60 \%$ taxation for individuals' incomes (TII);

- state custom, enrolled to the local authority budgets due to the location of operating and issuing documents;

- excise taxation for excisable goods retail sale by the entities;

- taxation for the income of the public ownership enterprise;

- local taxations and collections;

- single tax;

- rental payments;

- payment for licensing, certifying and definite types of household activity;

- payment for the location of temporary free finance of the corresponding local budgets;

- funds from the sale of the ownerless property;

- concession payments of public ownership items;

- payment for administrative services providing;

- administrative fees and penalties;

- funds, earned by the participants of the procurement procedures in the cases, stipulated by the Law of Ukraine "About State Procurement Execution";

- $80 \%$ of funds for passing in gold, platinum, platinum group metals and precious stones in the form of scrap and debris;

- $25 \%$ of ecological taxation

- other incomes, which are subjected for enrollment to the corresponding local budgets [6, c.23-34]. 
Structure of the local budgets incomes of 2016 is exposed in picture 3 .

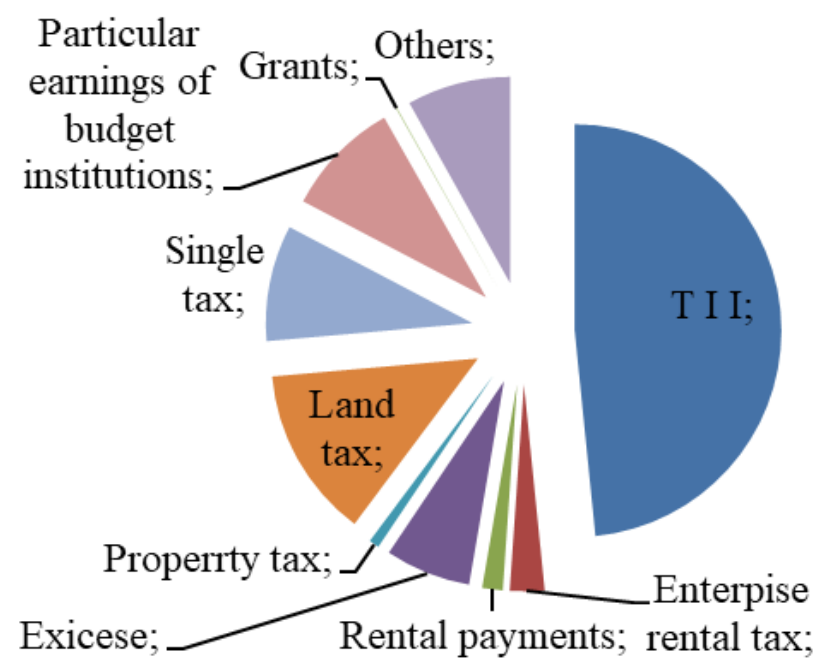

Fig. 3. Structure of Local Budgets Income in 2016 (excluding inter-budget transfers)

Source: has been calculated by the authors

Within the content of local budgets incomes, basic payments are the taxes for individuals incomes $(48,4 \%)$ and land payment $(13,4 \%)$, as the components of property tax.

Thanks to the changes of tax and budget legislature within the decentralization context, the amount of the personal incomes in local budgets of the joint communities increased twice as much (over 1046 million UAH), compared to 2015 (from 827 million UAH to 1873 million UAH). [9, c.42]

Definite types of budget incomes and expenditures are able to turn into budget motivators, in case if mobilization methods, directions and regulations of budget funds usage will be correlated to community interests and economic interests of the entities.

Neither incomes themselves, nor their separate types can operate in the role of motivators, as far as their objectives are to provide the sufficient amount of budget fund. It is possible to turn budgets incomes into the motivators by means of identifying the regulations of the usage of some definite taxes and collections.

The Constitution or The Law determine key powers and functions of the local authority bodies, according to the European Charter of Local Authority. Major Powers of the local self-authorities of Ukraine are generally enshrined in Chapter 143 of the Main Law, and detailed in the Law "About Local Self-authority of Ukraine" and in the number of other specialized laws. The Law of Ukraine "About Local Self-authority of Ukraine" stipulates the division of the powers of the self-authority bodies into personal and delegated ones [8, c.78].

The major duty of the local budgets within the expenditures structure is the most impressive [7]. For example, following from the results of 2017, structure of the local level budgets expenditures proves, chiefly, their social focusing. 101340 million UAH (70,7\% of overall local Ukrainian budget amount) had been spent for social protection and social support, maintenance of the components of social-cultural sphere (education, health care, culture, art, mass media, youth programs, physical culture and sport). Payment amounts of the local budgets expenditures, within the planning process, are identified separately for each branch and take into consideration general resources and priority of the expenditures.

Alongside planning process, calculated amounts of the local budgets expenditures are determined separately for each branch, concluding general resources and priority of the expenditures.

Current calculations are performed on the basis of mutual regulating of budget sufficiency per person (state regulation, health care, culture and art, physical culture and sport, social programs concerned with family, women, youth and children), per child or pupil - education, per social assistance consumer - social protection, social support and others [7].

The only orientation for the evaluation of real expenditures' correlation with average Ukrainian are the regulations of budget sufficiency. These regulations are determined by the Ministry of Finance and specialized Ministries in order to calculate the transfer.

It is worth differentiating the regulations of the social needs and the regulations of the budget sufficiency. As far as the firstly mentioned regulations are the indicators of the scientifically 
backgrounded needs, required for the branch functioning, then the latest ones - are determined by the need for resource and demand balance.

According to the standards of the Law of Ukraine "About Local Self-authority in Ukraine" (paragraph 3 part $1 \mathrm{ch} .26$ ), local boards form an executing board committee, estimating its number and staff composition. These standards had been confirmed by the decision of the Constitutional Court of Ukraine, adopted on 22.05.2008, №10-pп/2008, which recognized the amendments to the Law of Ukraine "About Local Self-authority in Ukraine" as non-constitutional (while adopting the Law of Ukraine "About State Budget of Ukraine for 2008), which deals with the approval of the board executive bodies' structure, general number of the board staff and its executive bodies "according to the typical staff, approved by the Cabinet of Ministers of Ukraine".

While applying these standards, it is worth comprehending the order of the definite subdivisions' or departments formation of the Executive Committee of the board, joint by the territorial communities, which expects consideration of the current needs and possibilities.

While the majority of the cities of regional importance have already identified the structure of their executive committee, the newly created joint territorial communities have just started moving towards it. Although, plain copying of the structure, similar in number with the territorial community, cannot produce the expected results.

The problems of the joint communities vary from the cities of regional importance. Various distance from the utmost locations of the settlements distinguished the citizens of the community, and this distinguishment led to misunderstanding, and, finally, unacknowledgment of each other. Many citizens of some definite settlements have never visited the opposite location of the community. Now "de jure" they have become one integral unity. Consequently, the task of the local self-authority bodies is "de facto" to compose it all together into one integral unity, and these actions must not be plain reproduction of the original. For example, it is not worth for all joint communities to create separate authorities of education or culture, as long as providing them legal entity status.

On the other side, the need for creating land or judicial authority may occur, as well as possible need for creating separate departments of some services in the distant settlements, and others.

As for the staff composition of the new created authorities and departments, it is not reasonable to hurry in setting up the whole staff at once. The approach must be creative and deliberate. In this case, it is important to use intellectual potential of the citizens of the community rationally.

The expenditures of the budget, unlike the incomes, can be correlated to budget motivators. Direct transformation of the budget expenditures into motivators is possible by means of choosing the progressive directions of budget financing (for improving branch and territorial structure of the economy, prior supply to the branches and production, ensuring high speed development), forms and regulations of budget finance distribution among definite subjects of budget relationship.

Budget expenditures correspond with the earnings. Therefore, while planning, using even minor part of the expenditures for something that will later increase your incomes would prove to be a reasonable decision [4, c. 34-45].

Conclusions. As a result, nowadays, after having been created in the form of legal entities, joint territorial communities (as it occurs in Poland, Czech Republic and other European states) compose local self-authority budget and distribute this finance individually, or through the bodies of self-authority, created by them. Following-on from our research, this peculiarity has become the major impulse for constructing a renovated structure of Ukrainian budget system including clear distinguishing of the budgets of territorial communities.

\section{REFERENCES}

1. Budget Code of Ukraine: The Law of Ukraine of 08.07.2010 № 2456 - VI. [Web resource]. - Retrieved from: http://zakon2.rada.gov.ua/laws/show/2456-17

2. Zamkova N.L. State Finance: textbook. / N.L.Zamkova, I.V.Hnydiuk, Y.A.Romanovska. - Vinnytsia: Publishing-editing department VITE KNUTE, 2015. - $464 \mathrm{c}$.

3. Official web-site of the Ministry of Finance of Ukrain. [Web resource]. - Retrieved from: http://www.minfin.gov.ua/news/bjudzhet

4. Planning and Management of the Financial Resources of a Territorial Community / O.Kyrylenko, B.Malynyak, V.Pysmennyi, V.Rusin / Association of Ukrainian cities - K., TOV "PIDPRYEMSTVO "VNA", 2015. - 396 c.

5. About Submitting Changes to the Budget Code of Ukraine as for Inter-budget Relationship Reforming: The Law of 28.12.2014 №79-VIII [Web resource]. - Retrieved from: http://zakon3.rada.gov.ua/laws/show/79-19 
6. Tkachuk A.F. About Budget and not only this. Specially assigned for joint territorial communities / Anatoliy Tkachuk, Nina Natalenko. - K.: IKC “Legal Status", 2016. - 76 c.

7. Chugunov I.Y. Formatting Budget Expenditures within the System of Social-economic Development of the Country / I.Y.Chugunov, I.M.Gnatyuk // University Economic Journal. - 2016. - Issue 28(1). - P. 217-226. Retrieved from: http://nbuv.gov.ua/UJRN/ecvu_2016_28(1)_31

8. Storonyanska I. Risks of administrative and financial decentralisation: theoretical hypotheses and empirical assessment / I. Storonyanska, L. Benovska // Economic Annals-XXI (2017), 166(7-8), 76-79

9. Bogolib T. Budgetary system of Ukraine: a new reality and global challenges / T. Bogolib // Economic Annals-XXI (2016), 156(1-2), 41-43

10. Boiko S. Individual income tax in the formation of financial resources of the enlarged government / S.Boiko, O. Drahan // Economic Annals-XXI (2016), 161(9-10), 35-38 